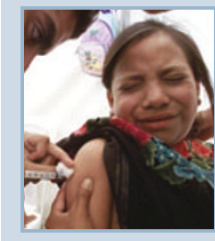

p359 Shot down:

Vaccines for cervical cancer are impractical, experts say.

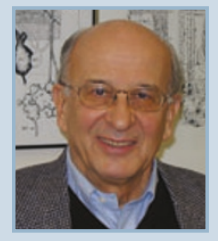

p362 A rare breed: Neuroscientist Pasko Rakic embraces the best of science and art.

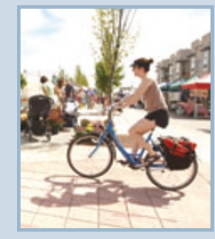

p363 Fighting fat: The obesity epidemic is spawning some unusual solutions.

\title{
Bitter criticism sours new diabetes research plan
}

On the face of it, the Juvenile Diabetes Research Foundation's (JDRF) new research program to fight juvenile diabetes seems like a good thing. The fast-track, milestone-driven program pledges an innovative route to drug candidates for juvenile, or type 1, diabetes. But several researchers have opted out of the program, sharply criticizing the model as inappropriate for academic research.

The JDRF on 2 March launched the first phase of its program on beta cell regeneration, a process that would replace the insulin-producing pancreatic beta cells destroyed in type 1 diabetes. The team includes several beta cell experts and non-diabetes regeneration experts.

But many big names in beta cell biologyincluding a few who, at a spring 2004 workshop, helped the JDRF set the research agenda-are notably missing. Some of those researchers say regeneration is just the latest in a long line of research trends-including gene therapy, islet transplants and embryonic stem cells - that the JDRF has embraced to satisfy its donors. But the charity is not sustaining support to any one area long enough for real progress, they say.

Richard Insel, JDRF's executive vice president for research, says there is a natural overlap between work in transplants, embryonic stem cells and regeneration. "It is incumbent upon us to promote all of the different areas," he says, adding that the regeneration program does not detract from other projects.

The JDRF is a big player in diabetes research, funding nearly $40 \%$ of all studies on type 1 diabetes. The regeneration program, which represents five percent of the charity's annual research budget, is at least $\$ 10$ million for two years, during which 16 investigators in five countries will collaborate closely, sharing data in monthly conference calls and quarterly progress reports.

Insel says donors like having that accountability written into the program. But he says some high-profile scientists opted out of the program because they could not commit to the heavy time requirements, or were uncomfortable with the near real-time sharing of data.

Because most researchers in the community receive funding from the JDRF, they asked not to be quoted. But off the record, many said that the program's level of oversight is unacceptable, and may be restrictive to the nonlinear manner of scientific discovery.

Mark Keating, a cardiac regeneration expert at Children's Hospital Boston who is not funded

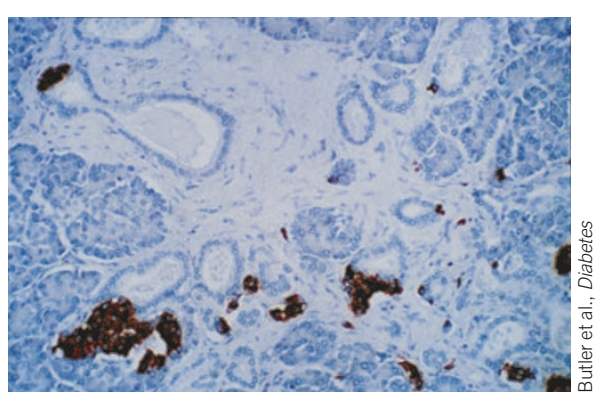

Beta blockers: Some experts say beta cell regeneration in humans is poorly understood. by the JDRF, says he would not have signed up for such controlled oversight. "It's an interesting experiment," Keating says. "But it's very difficult to coerce academics to do this-it's like herding cats, really."

Beta cells destroyed by autoimmunity in type 1 diabetes have been shown to regenerate in animal models and possibly even in humans (J. Clin. Invest. 115, 5-12; 2005). These advances_-and the popularity of regenerative medicine- - have generated a flurry of money and interest.

Preliminary results are promising and a couple of drug candidates are already in trials. But how regeneration in humans occurs, and under what conditions, is still up for heated debate.

Too much emphasis is being placed on mouse models that have significant biological differences with humans, says Peter Butler, who works on human beta cells at the University of California in Los Angeles. "There have been hundreds of papers on curing diabetes in mice and none in humans," Butler says.

Butler questions whether the JDRF's program can compete in drug discovery against pharmaceutical companies with far greater resources.

A two-year timeframe might also be rushing the science in a very early field, adds Massimo Trucco, director of the Diabetes Institute at Children's Hospital of Pittsburgh. "There's an old Italian saying, 'fast and well, they don't go together,"' Trucco says.

Kendall Powell, Denver

\section{Therapies come closer with 'cleaner' stem cell lines}

Scientists have for the first time created a line of human stem cells without using animal cells, a potential source of contaminants. The breakthrough raises hopes that researchers can grow cells that are safe for human therapy.

Most available stem cell lines, including those approved for US federal funding, were either generated or grown on animal feeder cells, a nourishing scaffold often used to support the cells. Scientists have been concerned that these animal products could pass viruses or other contaminants to the human cells, making them unfit for clinical use. In January, scientists announced that at least one of the Bush-approved stem cell lines was contaminated with an animal sugar (Nat. Med. 11, 228-232; 2005).

Researchers had previously developed ways to grow embryonic stem cells without using animal cells (Nat. Methods 2, 185-191; 2005), but had yet to create a new cell line without the feeder cells. Robert Lanza and colleagues at Advanced Cell Technology in Worcester, Massachusetts, announced in March that they have derived a new cell line free of any animal cells or serum. They extracted stem cells from a human embryo and grew them on a specially created sterile protein matrix. The cells maintained their ability to grow into different types of tissues, even after six months in the undifferentiated state. That report was published online in The Lancet.

Emily Singer, Boston

For more news and analysis go to news@nature.com www.nature.com/news 